Sharif University of Technology
Scientia Iranica
SCIENTIA
I RAN ICA
http://scientiairanica.sharif.edu

\title{
Improving shallow foundations resting on saturated loose sand by a zeolite-cement mixture: A laboratory study
}

\author{
S. Salamatpoor ${ }^{\mathrm{a}}$, Y. Jafarian ${ }^{\mathrm{b}, *}$, and A. Hajiannia ${ }^{\mathrm{a}}$ \\ a. Department of Civil Engineering, Najafabad Branch, Islamic Azad University, Najafabad, Iran. \\ b. Geotechnical Engineering Research Center, International Institute of Earthquake Engineering and Seismology, Tehran, P.O. Box \\ 19395-3913, Iran.
}

Received 6 January 2018; received in revised form 2 March 2018; accepted 5 March 2018

KEYWORDS
Sand stabilized;
Zeolite;
Unconfined
compression strength;
Small-scale 1g test.

\section{Introduction}

Soil improvement is one of the most practical subjects of geotechnical engineering. The improvement techniques are categorized commonly into physical, chemical, mechanical, and biological types that are, in general, aimed at modifying the unsuitable soil behavior, such as low bearing capacity and excessive

\footnotetext{
*. Corresponding author.

E-mail addresses: s_salamatpoor@sci.iaun.ac.ir ( $S$ Salamatpoor); yjafarianm@iiees.ac.ir (Y. Jafarian); alborzhajian@pci.iaun.ac.ir (A.Hajiannia)
}

doi: $10.24200 /$ sci. 2018.50153 .1567

\begin{abstract}
Improvement operation of sands is carried out frequently by cement together with several other additives. Common additives have high manufacturing cost and negative environmental impact during their manufacturing process and recycling in nature. Zeolite a treated sand, without the negative deficiencies of the common additives. In this study, Unconfined Compression Strength (UCS) and small-scale $1 \mathrm{~g}$ model tests were conducted to foundations resting on zeolite pad, respectively. The results of this study demonstrate that the UCS of the cemented sand samples increases when the cement is replaced by zeolite at of zeolite to cemented sand mixture causes an increase in terms of the improvement rate between $40 \%$ and $125 \%$ and increases the Bearing Capacity Ratio (BCR) of the strip freated by zeolite pad in the range of $11 \%$ to $420 \%$. In addition, zeolite pad of the Settlement Reduction Ratio (SRR).
\end{abstract}

(C) 2018 Sharif University of Technology. All rights reserved. 
seeking the application of sustainable materials with the least amount of energy and costs in their production process, as well as a reduction in environmental impacts during their recycling process in nature. One of these alternatives is a natural zeolite, which reduces the environmental drawbacks of cement. Moreover, utilizing other additives to the cemented sand improves the brittle behavior of cemented sand. In recent years, utilizing pozzolanic materials as a substitute for a portion of the applied cement has become quite common to reduce probable environmental impacts, modify soil specifications, and save the costs.

Natural zeolite is a pozzolanic material made up of volcanic material that contains large quantities of reactive silicon dioxide $\left(\mathrm{SiO}_{2}\right)$ and aluminum oxide $\left(\mathrm{AI}_{2} \mathrm{O}_{3}\right)$. Calcium hydroxide $\left(\mathrm{Ca}(\mathrm{OH})_{2}\right)$ produced by the hydration of Portland cement reacts with zeolite, causing chemical improvement of the interfacial microstructure between the blended cement paste [35]. Generally, natural zeolite, which contains high pozzolanic activity, leads to the improvement of the mechanical strength and durability of cement and concrete properties [6].

Most studies on zeolite are focused on the improvement of the mechanical features of concrete, and its performance in geotechnical engineering field has been rarely addressed. Tuncan et al. [7] studied the features of mixed zeolite-Bentonite in terms of strength parameters. They conducted UCS and triaxial tests, and found that adding zeolite to the mixture increases the specimens' strength remarkably. Furthermore, the $B / Z$ (Bentonite to Zeolite) ratio of 0.1 is known as the ideal mixing ratio in the backfill construction.

The studies conducted on the bearing capacity of the foundations constructed on loose sand clearly show that such foundations may experience a significant lack of shear strength due to earthquakeinduced liquefaction [8]. Furthermore, Jafarian et al. [9] investigated bearing capacity and settlement of strip and square footings resting on saturated sand, subjected to various intensities of upwards seepage. Although extensive researches have been carried out for settlement reduction of foundations in such conditions, more investigations seem to be required to evaluate various soil improvement techniques for foundation treatment. Dash et al. [10] assessed the impact of geocell reinforcement on the bearing capacity of strip foundation on sand. They concluded that the best result could be obtained when the ratio of geocell installation depth to foundation width is 0.1 .

In this paper, the mechanical effect of zeolite on the shear strength of cemented sand is investigated through the Unconfined Compression Strength test (UCS) within the first stage. Reviewing the results suggests an optimum proportion of zeolite among all the considered proportions and introduces an ideal combination of the stabilization of cemented sand samples. Subsequently, several experiments are conducted using small-scale $1 \mathrm{~g}$ model tests to investigate the behavior of strip foundations resting on the zeolitecemented sand pads. In the following sections, the testing procedure and the results are explained in detail; in addition, the effects of the thickness of the zeolite pad on bearing capacity and settlement of shallow foundation will be discussed.

\section{Experimental investigations}

\subsection{Material properties}

\subsubsection{Sand}

The soil used in this study is the Babolsar sand sampled from the southern shores of the Caspian Sea in Mazandaran province, Iran. It is a poorly graded sand that is classified as SP according to the Unified Soil Classification System (USCS) (ASTM D422, [11]) with $\left(\gamma_{d}\right)_{\max }=17,\left(\gamma_{d}\right)_{\min }=15.1, G_{s}=2.78$, $D_{50}=0.24 \mathrm{~mm}$, and $C_{u}=1.8$. Figure 1 represents the grains' size distribution curve of the sand. The geographical coordinate of the sampling site is $36^{\circ} 42^{\prime} 34.4^{\prime \prime} \mathrm{N} 52^{\circ} 38^{\prime} 04.2^{\prime \prime} \mathrm{E}$.

The groundwater is near the ground surface and also the region has a high seismic potential due to the Khazar fault. In the past, several catastrophic earthquakes took place near the Babolsar city such as the Bandpey 1957 earthquake $\left(M_{w}=7\right)$, which claimed more than 1500 human lives and destroyed 120 villages. Therefore, liquefaction occurrence is likely, and investigating the behavior of shallow foundations on the loose saturated Babolsar sand in the area seems to be essential. Jafarian et al. [12] evaluated the monotonic behavior of the Babolsar sand through the triaxial tests under isotropic and anisotropic consolidations. Moreover, Jafarian et al. [13] evaluated the shear strain-dependent dynamic properties of this sand using

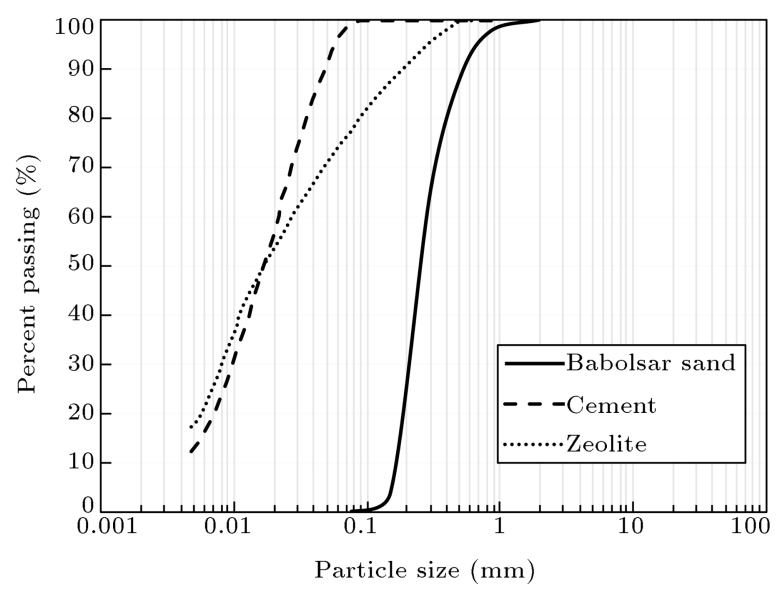

Figure 1. Particle size distribution curves of Babolsar sand, cement, and zeolite. 
a resonant column and cyclic triaxial experiments. The experimental results indicate that confining pressure has an important influence on the shear modulus of the tested samples and, by increasing mean confining pressure, the effect of relative density and initial stress anisotropy on the shear modulus increases. In addition, Salamatpoor and Salamatpoor [14] compared the liquefaction potential of the Babolsar sand with thirteen case histories using the concept of liquefied shear strength ratio. The results of these studies indicate that the Babolsar sand is potentially susceptible to significant strain softening due to monotonic and cyclic loads. Since the region is densely populated and numerous shallow foundations are constructed, sand improvement studies are necessary to reduce the probable risks arising from the shear failure of foundations in these areas.

\subsubsection{Cement}

In this paper, Portland cement type II (ASTM C150/C150M-17 [15]) was utilized in the experiments. This type of cement, which is appropriate for structures exposed to soil or water containing sulfate ions, was obtained from Mazandaran Cement Company as the most widely used cement in the construction industry in the North of Iran.

\subsubsection{Zeolite}

The natural zeolite of the clinoptilolite type was utilized in this study, which was extracted from the Aftar Mine located $30 \mathrm{~km}$ far from Semnan Province in the central region of Iran $\left(35^{\circ} 37^{\prime} 44^{\prime \prime} \mathrm{N} 53^{\circ} 01^{\prime} 22^{\prime \prime} \mathrm{E}\right)$. Based on the recent exploration study, the proven reserves of zeolite in the mine are over 600 thousand tons; currently, 85 percent of the total zeolite extraction in Iran is extracted from this mine.

The zeolite is classified as low plasticity silt (ML) according to the Unified Soil Classification System with $\left(G_{s}=2.2\right)$, and its color is a light cream. Figure 1 represents particle size distribution curves of the sand, cement, and zeolite used in this study. Furthermore, Table 1 presents the physical characteristics and chemical composition of the cement and zeolite, respectively.

\subsection{Description of experiments, sample preparation, and testing procedure}

In this study, two series of experiments were conducted. In the first series, to evaluate the mechanical behavior of zeolite-cemented sand mixtures, Unconfined Compressive Strength (UCS) tests were performed to determine an optimum proportion of zeolite as a complementary additive to the cemented sand. The optimum proportion of zeolite denotes the most efficient amount of this substance in the sand that results in the highest strength enhancement. In the second series of the experiments, several small-scale $1 \mathrm{~g}$ model tests were performed to investigate the behavior of strip
Table 1. Physical properties and chemical composition of cement and zeolite.

\begin{tabular}{lcc}
\hline Details & Cement & Zeolite \\
\hline $\mathrm{SiO}_{2}$ & 21.90 & 67.79 \\
$\mathrm{Al}_{2} \mathrm{O}_{3}$ & 4.86 & 13.66 \\
$\mathrm{Fe}_{2} \mathrm{O}_{3}$ & 3.30 & 1.44 \\
$\mathrm{CaO}$ & 63.32 & 1.68 \\
$\mathrm{Na}{ }_{2} \mathrm{O}$ & 0.36 & 2.04 \\
$\mathrm{~K}_{2} \mathrm{O}$ & 0.56 & 1.42 \\
$\mathrm{MgO}$ & 1.15 & 1.20 \\
$\mathrm{SO}_{3}$ & 2.10 & 0.50 \\
$\mathrm{~L} . \mathrm{O} . \mathrm{I}$ (Loss On Ignition) & 2.40 & 10.23 \\
$\mathrm{C}_{3} \mathrm{~S}$ & 47.98 & - \\
$\mathrm{C}_{2} \mathrm{~S}$ & 26.61 & - \\
$\mathrm{C}_{3} \mathrm{~A}$ & 7.30 & - \\
$\mathrm{C}_{4} \mathrm{AF}$ & 10.04 & - \\
$\mathrm{Specific}_{\text {gravity }}$ & 3.11 & 2.2 \\
$\mathrm{Blaine}\left(\mathrm{m}^{2} / \mathrm{kg}\right)$ & 305 & 400 \\
Initial setting time (min) & 115 & - \\
\hline
\end{tabular}

Note: Chemical compositions of NZ and Portland cement were determined according to ASTM C114-11 [16].

foundations resting on a pad pre-cast by the selected optimum proportion of zeolite. The details of the testing process will be described later.

\subsubsection{Unconfined compressive strength test}

The aim of the present investigation in this section is to study the effect of adding a variable amount of cement and zeolite additives on the strength of sandadditive samples. The UCS test (conducted according to ASTM D2166 [17]) has been selected to investigate the optimum proportion of zeolite. This test is a quick, inexpensive, useful, and prevalent test among the other geotechnical laboratory tests, deserving the scope of this part of the current study. The soil samples were prepared in a cylindrical shape with $49 \mathrm{~mm}$ diameter and $98 \mathrm{~mm}$ height (with the ratio of 1:2). A series of laboratory tests on the Babolsar sand were conducted with the cement contents at the ratios of $3 \%$ and $7 \%$ (relative to the dry soil mass) and replacement of cement by zeolite at the rates of $0,20 \%, 40 \%, 60 \%$, and $80 \%$ (see Table 2).

Initially, the sand was oven-dried for 24 hours and was mixed gradually with cement and zeolite (based on the scheduled ratio). Then, $10 \%$ of the dry soil mass of clean water was added to the soil continuously and mixed well to form a homogeneous paste. Regarding the compaction method proposed by Ladd [18], the mixture was dispersed in three separate layers in the mold and, then, compacted before casting the upper layer. The surface of the lower layers was slightly scarified to improve the interlock between the layers, as 
Table 2. Physical properties of unconfined compression strength test used in this study.

\begin{tabular}{|c|c|c|c|c|c|}
\hline No. & Series & $\begin{array}{c}\text { Sand } \\
(\%)\end{array}$ & $\begin{array}{c}\text { Cement } \\
(\%)\end{array}$ & $\begin{array}{c}\text { Zeolite }(\%) \\
\text { (replacement) }\end{array}$ & $\begin{array}{c}\text { Curing } \\
\text { days }\end{array}$ \\
\hline 1 & A & 97 & 3 & 0 & 7 \\
\hline 2 & A & 97 & 3 & 20 & 7 \\
\hline 3 & A & 97 & 3 & 40 & 7 \\
\hline 4 & A & 97 & 3 & 60 & 7 \\
\hline 5 & A & 97 & 3 & 80 & 7 \\
\hline 6 & B & 97 & 3 & 0 & 14 \\
\hline 7 & B & 97 & 3 & 20 & 14 \\
\hline 8 & B & 97 & 3 & 40 & 14 \\
\hline 9 & B & 97 & 3 & 60 & 14 \\
\hline 10 & B & 97 & 3 & 80 & 14 \\
\hline 11 & $\mathrm{C}$ & 97 & 3 & 0 & 28 \\
\hline 12 & $\mathrm{C}$ & 97 & 3 & 20 & 28 \\
\hline 13 & $\mathrm{C}$ & 97 & 3 & 40 & 28 \\
\hline 14 & $\mathrm{C}$ & 97 & 3 & 60 & 28 \\
\hline 15 & $\mathrm{C}$ & 97 & 3 & 80 & 28 \\
\hline 16 & $\mathrm{D}$ & 93 & 7 & 0 & 7 \\
\hline 17 & $\mathrm{D}$ & 93 & 7 & 20 & 7 \\
\hline 18 & D & 93 & 7 & 40 & 7 \\
\hline 19 & D & 93 & 7 & 60 & 7 \\
\hline 20 & $\mathrm{D}$ & 93 & 7 & 80 & 7 \\
\hline 21 & $\mathrm{E}$ & 93 & 7 & 0 & 14 \\
\hline 22 & $\mathrm{E}$ & 93 & 7 & 20 & 14 \\
\hline 23 & $\mathrm{E}$ & 93 & 7 & 40 & 14 \\
\hline 24 & $\mathrm{E}$ & 93 & 7 & 60 & 14 \\
\hline 25 & $\mathrm{E}$ & 93 & 7 & 80 & 14 \\
\hline 26 & F & 93 & 7 & 0 & 28 \\
\hline 27 & $\mathrm{~F}$ & 93 & 7 & 20 & 28 \\
\hline 28 & $\mathrm{~F}$ & 93 & 7 & 40 & 28 \\
\hline 29 & $\mathrm{~F}$ & 93 & 7 & 60 & 28 \\
\hline 30 & $\mathrm{~F}$ & 93 & 7 & 80 & 28 \\
\hline
\end{tabular}

shown in Figure 2(a). To minimize the friction between the mold and sample, before pouring the mixture into the mold, the inner surface of the mold was lubricated. As a result, no crack was observed in the sample due to the mold removal. After 6 hours and reaching the initial set, the mold was removed and the samples were cured in plastic bags for 7,14 , and 28 days in a humid room with the temperature of $23 \pm 2 \mathrm{C}^{\circ}$ as well as the relative humidity above $95 \%$, as seen in Figure 2(b). After the curing time, the samples were placed under vertical automatic loading at the rate of $1 \mathrm{~mm} / \mathrm{min}$ without any hit and vibration. Liu and Evett [19] reported that failure in UCS test occurred in the form of either the largest amount of load per unit area or the load per unit area at $15 \%$ axial strain. Figure 2(a)(c) show the tests' processes including the compaction, the scarifying of the samples in the mold, placing the samples in plastic bags for curing, and also failure types of stabilized samples (Figure 2(c)).

\subsubsection{Small-scale $1 \mathrm{~g}$ model test}

The equipment used in this part of the study consists of a frame, transparent tanks, and measuring instruments. The frame, carrying the applied load via the jack, is composed of IPE 16 screwed to the rigid foundation with eight M22 bolts. In addition, the angle 


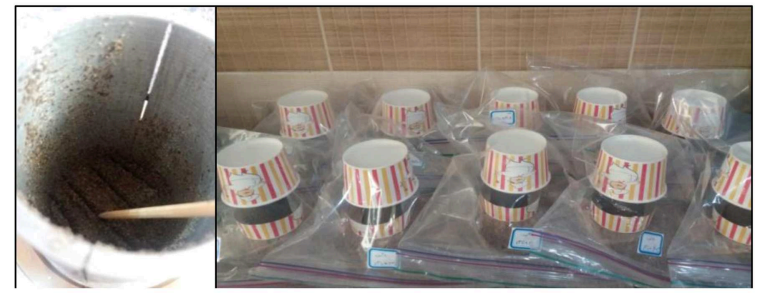

(a)

(b)

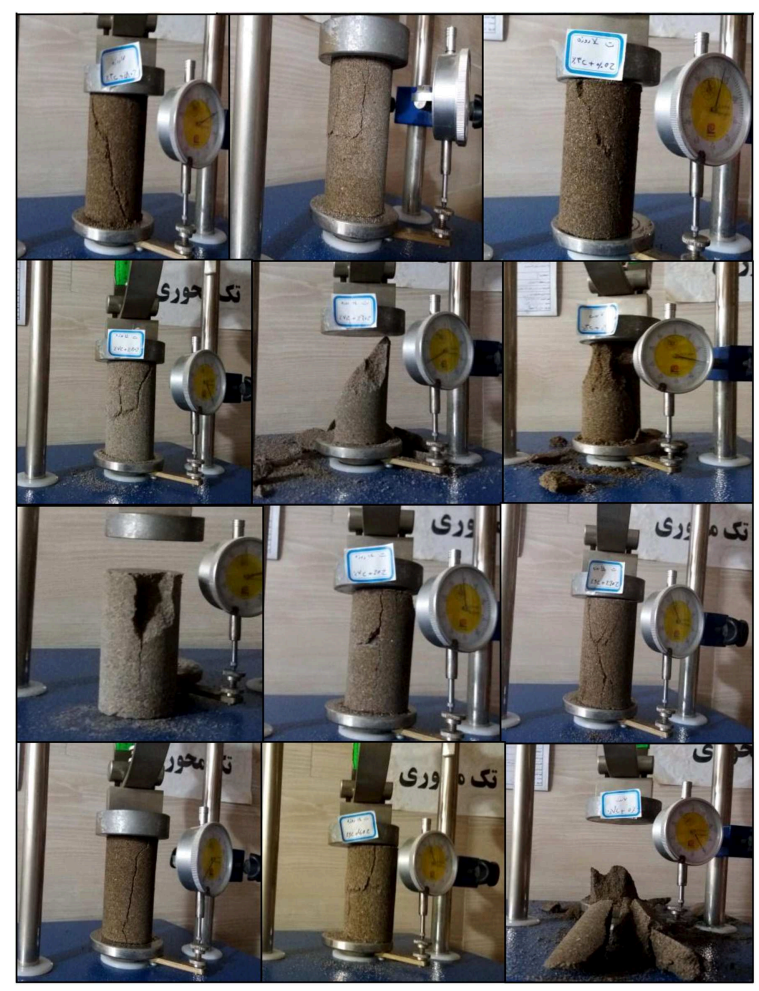

(c)

Figure 2. (a) Compaction processes and scarifying of the sample in the mold. (b) Placing the samples in plastic bags for curing. (c) Failure types of stabilized samples.

bars and reinforcements were welded to the frame to avoid any possible displacement. The transparent tank, designed as a rigid box, was made up of 4 sheets of a 20-mm-thick acrylic plate with $94 \mathrm{~cm}$ length, $40 \mathrm{~cm}$ width, and $94 \mathrm{~cm}$ height. In fact, for visual observation of soil deformation underneath the foundation or, in other words, tracking the wedge failure behavior, the tank was made up of transparent sheets.

To strengthen the test tank, a metal frame was used in conjunction with all the transparent walls. The strip footing with $15 \times 40 \mathrm{~cm}$ dimensions was made with a thick steel sheet, and some stiffeners were welded to the upper part of the sheets to ensure rigidity. Since the inside width of the box was equal to the length of the model foundations, a plain-strain condition was generally maintained. Before conducting the tests, for each test, some preliminary works were required for higher precision, such as calibrating the
Table 3. Physical properties of the pad used in this study.

\begin{tabular}{ccccc}
\hline No. & Series & Thickness & $\boldsymbol{C}(\boldsymbol{\%})$ & $\begin{array}{c}\boldsymbol{Z}(\boldsymbol{\%}) \\
\text { (optimum) }\end{array}$ \\
\hline 1 & $\mathrm{~A}$ & $B / 6^{*}$ & $3 \%$ & 40 \\
2 & $\mathrm{~A}$ & $B / 6$ & $7 \%$ & 40 \\
3 & $\mathrm{~B}$ & $B / 3$ & $3 \%$ & 40 \\
4 & $\mathrm{~B}$ & $B / 3$ & $7 \%$ & 40 \\
5 & $\mathrm{C}$ & $B / 2$ & $3 \%$ & 40 \\
6 & $\mathrm{C}$ & $B / 2$ & $7 \%$ & 40 \\
7 & $\mathrm{D}$ & $2 B / 3$ & $3 \%$ & 40 \\
8 & $\mathrm{D}$ & $2 B / 3$ & $7 \%$ & 40 \\
9 & $\mathrm{E}$ & $B$ & $7 \%$ & 40 \\
10 & $\mathrm{E}$ & $B$ & $3 \%$ & 40 \\
\hline
\end{tabular}

* $B$ : Width of foundation in the present study $(15 \mathrm{~cm})$.

load cell, dialing gauge, and depleting the piezometer tubes from the air. To achieve the required uniformity in the model, the sedimentation of soils in nature was mimicked for the sand deposition. First, the tank was filled with de-aired water up to $70 \mathrm{~cm}$ height. Then, the sands, dried in an oven for 24 hours, were gradually poured into the water from a constant height of $2 \mathrm{~cm}$ above the water surface by a sand rainer to achieve the desired loose density. Since the width and length of the testing tank were constant, the relative density was controlled by measuring the height (or volume) and also the weight of each layer. It was considered to reconstitute the model sand deposit at a relative density $\left(D_{r}\right)$ of $30 \pm 2 \%$ through a water sedimentation process.

The depth of sand deposit was $70 \mathrm{~cm}$ for the tests, which provides enough thickness for the failure surface caused by the applied load to the foundation plate. This issue was checked through the finiteelement modeling of the model test and the procedure of loading application. For the foundation width (i.e., $15 \mathrm{~cm})$ and the maximum surcharge $(100 \mathrm{kPa})$ specified in the experiments, the required sand depth and the total width of the model box were found to be $70 \mathrm{~cm}$ and $70 \mathrm{~cm}$, based on the finite-element modeling. For the sake of brevity, the details of the finite-element modeling are not given in this paper.

After filling the tank with sand and reaching the desired height, a zeolite pad with specific dimensions, shown in Table 3, produced and cured in the same manner as in the UCS test, was placed directly in the middle of the box. Then, the empty space on both sides of the pad was filled with sand so that the top of the pad reached the ground level. At this time, the strip foundation was placed exactly on the zeolite pad.

The vertical load was applied by a 1.5-ton jack, whereas the corresponding footing settlement was measured by a load cell and three dial gauges. Pore pressure at different levels was measured using piezometers, 


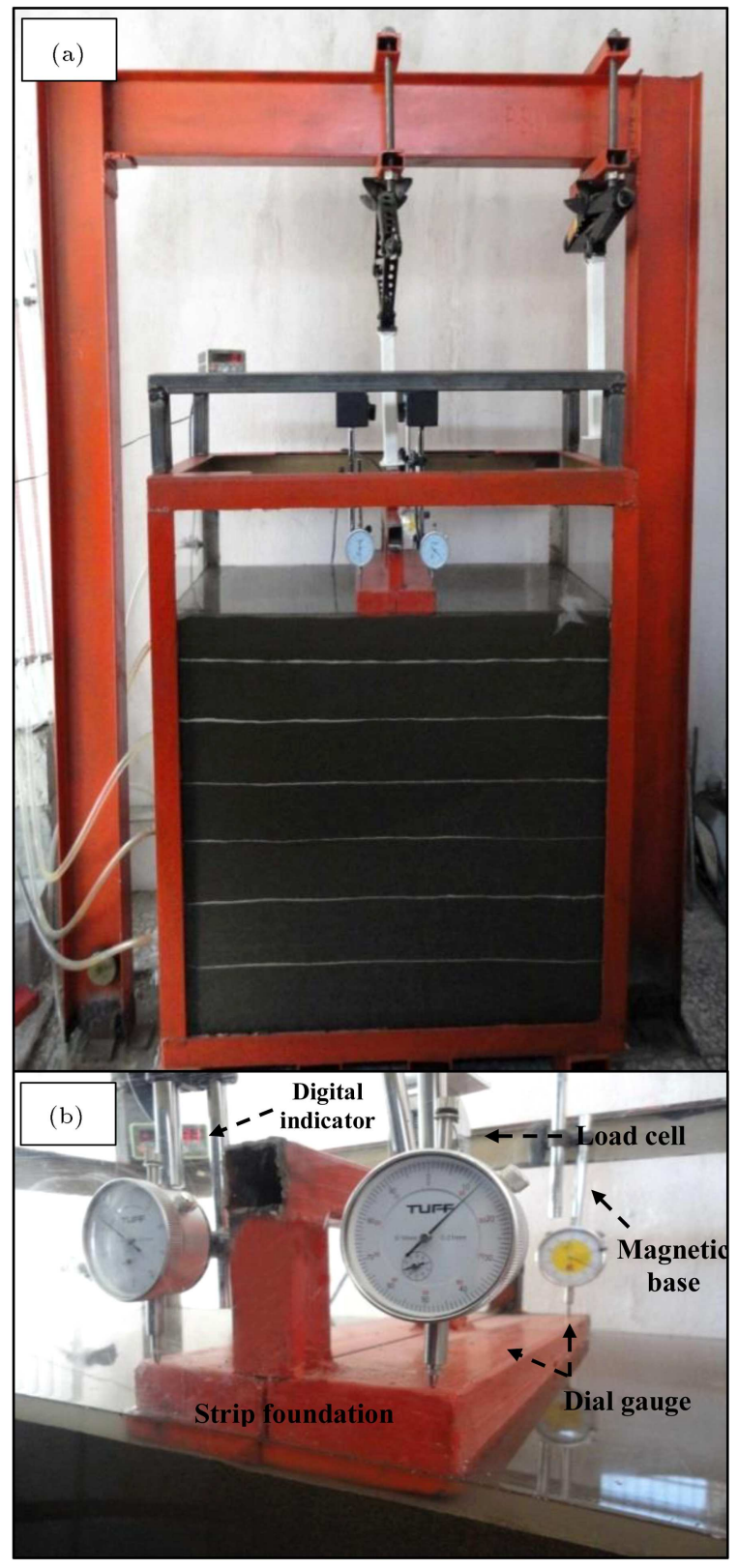

Figure 3. (a) View of the small-scale $1 \mathrm{~g}$ model test apparatus. (b) Setting test facilities and instrumentation on the strip foundation.

which are embedded every $15 \mathrm{~cm}$ beneath the foundation. The time of model preparation and testing procedure was about 8 hours, and all the described steps were repeated for each test. The devices and utilities were specifically designed and constructed for this study. Figures 3 and 4 illustrate the equipment and model preparation steps used in the experiments and also the schematic view of the experimental setup, respectively.

\subsubsection{Model scaling}

Physical modeling is divided into two categories: smallscale and full-scale models. Full-scale physical model-
Table 4. Scaling factor used to convert the parameters to prototype units [21].

\begin{tabular}{lc}
\hline \multicolumn{1}{c}{ Parameter } & $\begin{array}{c}\text { Scale factor } \\
\text { (prototype/model) }\end{array}$ \\
\hline Length & $N$ \\
Displacement & $N^{2-\propto^{*}}$ \\
Mass density & 1 \\
Stress and pressure & $N$ \\
Stiffness & $N^{\propto}$ \\
*For sands $\propto=0.5$. &
\end{tabular}

ing can simulate the real site conditions such as ground conditions, pressures, and stress levels. However, due to the difficulty of preparing the conditions for this type of modeling as well as its high cost, researchers encourage the use of small-scale physical models using the theory of similarity and scaling law.

Based on ASTM D1194-72 [20] for plate load tests in granular soils, replacement of a prototype with a plate $N$ times smaller in dimensions results in an ultimate bearing capacity $N$ times smaller than that of the prototype. In this study, a small-scale model with a ratio of 10 times smaller than the ratio of a hypothesized prototype was built. As the stress levels are low in a small-scale modeling, the stress-strain behavior of prototype was considered for the model, too. In addition, the scaling factors were assumed in this study. Table 4 shows the applied theory of scaling law defined by Wood [21].

Jafarian et al. [9] applied the Vargas-Monge [22] data and the brittleness index concept proposed by Bishop et al. [23] to account for the correlation of relative density and effective stress level between the model and the prototype scales. For the Babolsar sand (i.e., the sand used also in the current study), they decreased the relative density $\left(D_{r}\right)$ of the sand about $20 \%$ in the model scale in order to compensate for the 10 times smaller effective stress level, leading to more dilatant behavior in the model test. This type of scaling has been commonly used for the $1 \mathrm{~g}$ model tests dealing with large deformation problems (e.g., [24-27]). Therefore, in this study, the loosest state of the Babolsar sand in the $1 \mathrm{~g}$ box was achieved with $D_{r}=30 \pm 2 \%$ corresponding to $D_{r}=50 \%$ in the prototype scale using the adopted scaling factor $(N=10)$.

\section{Results and discussion}

\subsection{Results of the unconfined compression test}

Figure 5 represents stress-strain curves of the unconfined compression test of the specimens stabilized with cement contents of $3 \%$ and $7 \%$, considering various zeolite replacement values and three different curing times ( 7,14 , and 28 days). As observed, by increasing 


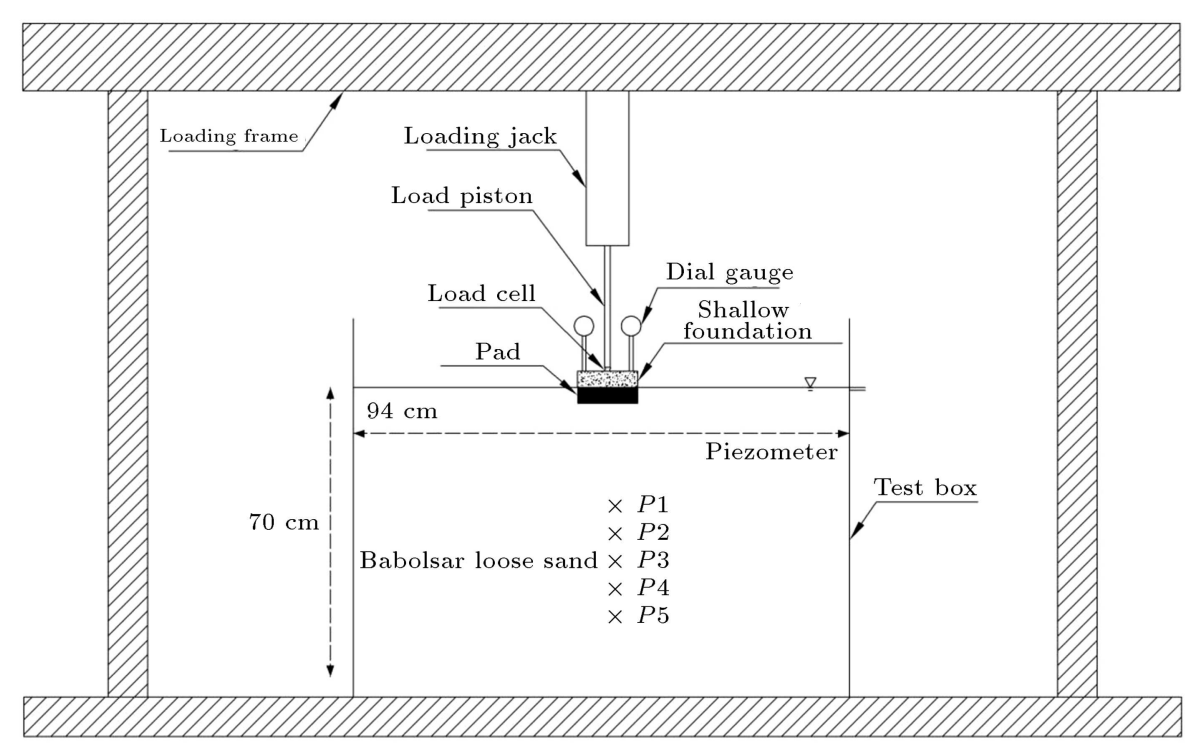

(a)

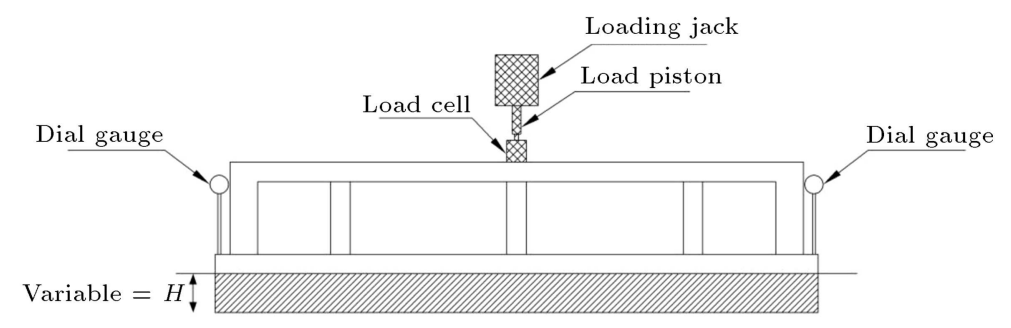

(b)

Figure 4. (a) Schematic view of the experimental setup. (b) Section view of the strip footing and pad (dimensions are in centimeters).

the amount of cement and samples' curing time, the maximum axial stress increases significantly and the corresponding strain decreases, showing the brittle behavior of the cemented sand samples. In addition, increasing the percentage of cement replacement by zeolite leads to the failure of samples at higher strains, demonstrating a reduction in the brittleness (plastic deformation) of zeolite-cemented sand specimens, compared to the cemented sample.

\subsection{Effects of zeolite on cemented sand strength}

The effect of increasing the amount of zeolite as cement replacement on the compressive strength of the stabilized samples is shown in Figure 6. The graph contains the maximum axial stress of all samples with cement contents of $3 \%$ and $7 \%$ and curing times of 7, 14, and 28 days. As observed in Figure 6, for the samples with curing time of 7 days and both of cement content, by increasing the amount of the cement replaced by zeolite, the compressive strength of the samples decreases due to the incomplete pozzolanic reaction in these mixtures. Moreover, by enhancing the percentage of zeolite as cement replacement for the 14 and 28 days' samples, the compressive strength initially increases, but then reduces. The highest compressive strength is obtained in an optimum amount of $40 \%$ replacement ratio. Increasing the cement content from $3 \%$ to $7 \%$ with $40 \%$ zeolite (as cement replacement) and the curing time of 28 days shows the enhancement of strength up to $238 \%$.

Moreover, in the case of adding $60 \%$ zeolite as cement replacement, the strength rate of samples with the curing time of 28 days and cement content of $7 \%$ increases up to $9 \%$, whereas it is only $2 \%$ for the ones with the curing time of 14 days and the cement content of $3 \%$. Therefore, it is found that the compressive strength of the cemented sand sample has an increasing trend by adding zeolite up to $60 \%$; in addition, the specimens with cement replacement of $80 \%$ by zeolite have lower strength compared with the cemented sand specimens.

The percentages of the selected cement content in this study are based on the average of the previous experiences on soil-cement, reporting $7 \%$ as the maximum value. However, for laboratory research, several researchers have reported $1 \%$ to $12 \%$ of cement for soil-cement stabilization [28]. It should be noted that using high percentage of cement for practical purposes, such as constructing backfills, sub-base of road and 

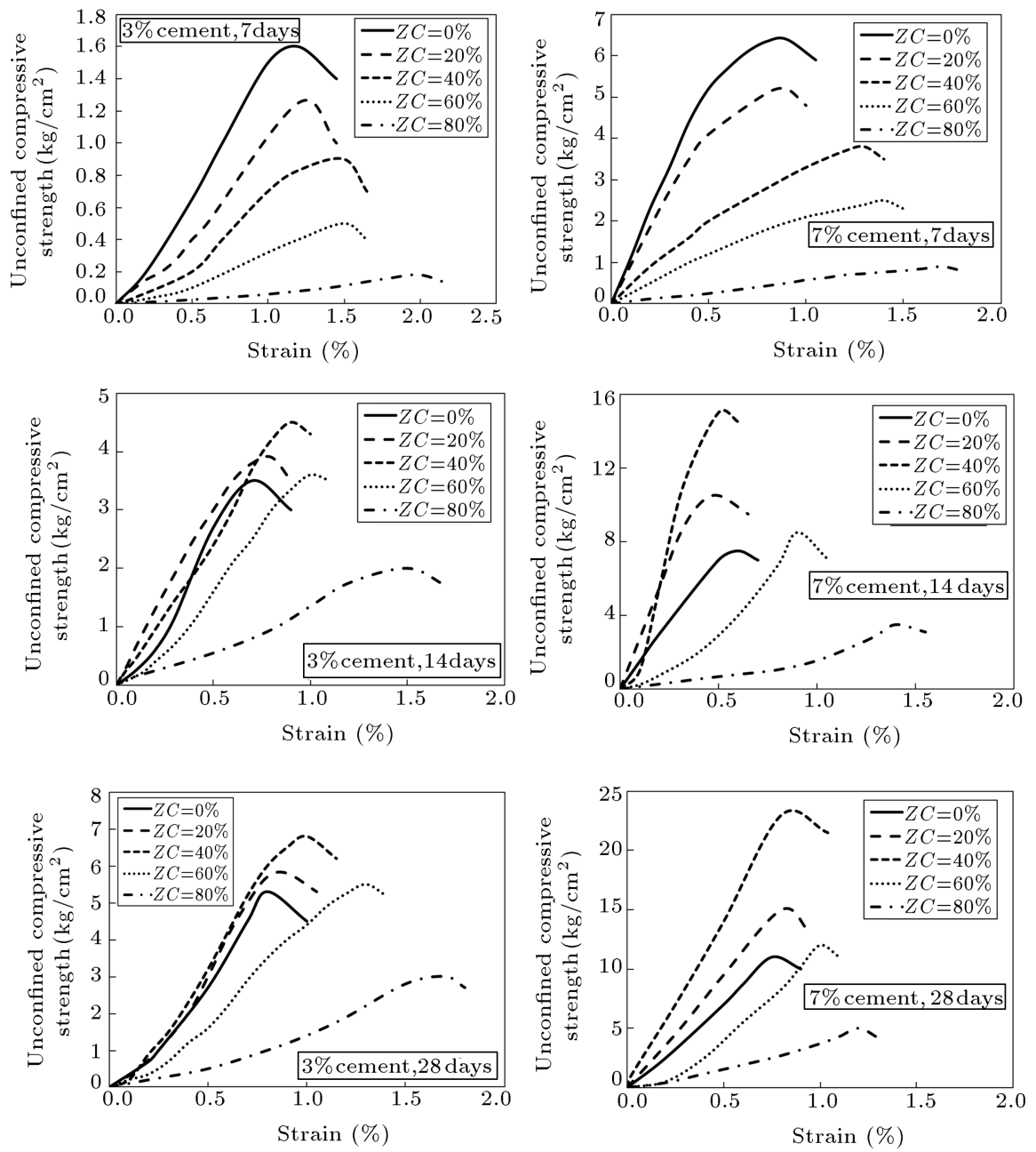

Figure 5. Stress-strain curves of zeolite-cemented sand samples.

railroads, etc., has restrictions due to the high cost (global price of cement) and the heat of hydration.

\subsection{Effects of curing time on compressive strength}

The samples' curing times represent one of the most important factors affecting the compressive strength. The factors influencing the given samples' UCS include water-to-cement ratio, particle size, type and amount of additives, and partial replacement of cement by mineral admixtures. The stress-strain curve was plotted for the specimens in an optimum amount of $40 \%$ replacement of cement by zeolite within 7,14 , and 28 days of curing times and two different cement amounts (see Figure 7). As observed, the higher the percentage of cement content is, the greater the effect of curing time of the samples will be. For example, for the samples with $7 \%$ cement, extending the curing time from 7 to 14 days increases the compressive strength up to 2.9 times, whereas extending the curing time from 7 to 28 days enhances the strength up to 5.8 times. These enhancements are made due to the improvement of the microstructure of the specimens resulting from the secondary reactions between the sample's particles and, consequently, the production of C-S-H gel.

\subsection{Effects of zeolite content on Improvement and Decline rates of specimens}

By increasing the zeolite content up to $40 \%$, the compressive strength of zeolite-cemented sand samples has an increasing trend compared to the cemented sample; however, more zeolite replacement leads to a decreasing trend in the compressive strength. Figure 8(a) shows the rate of compressive strength improvement of optimum zeolite-cemented sand samples in comparison with the cemented sample $\operatorname{(UCS}_{(s, c, z)}-$ $\left.\mathrm{UCS}_{(s, c)}\right) / \mathrm{UCS}_{(s, c)}$. It has been shown that the rates of improvement for cement content samples of $7 \%$ with two different zeolite quantities of $20 \%$ and $40 \%$ are respectively $52 \%$ and $125 \%$ higher than those of the cemented sand samples (with curing time of 28 days). This can be due to the greater reaction of zeolite with calcium hydroxide $\left(\left(\mathrm{Ca}(\mathrm{OH})_{2}\right)\right.$ in the cemented sample, together with a decrease in porosity 


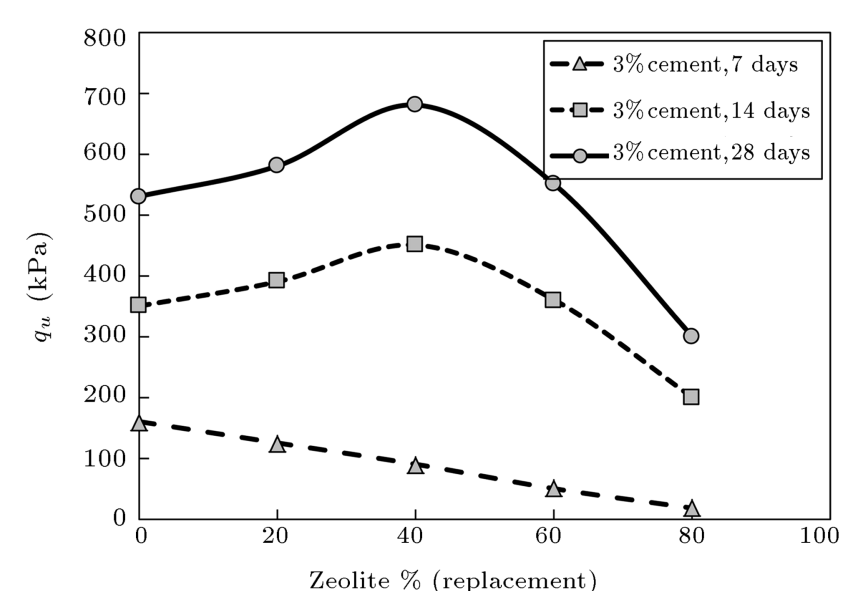

(a)

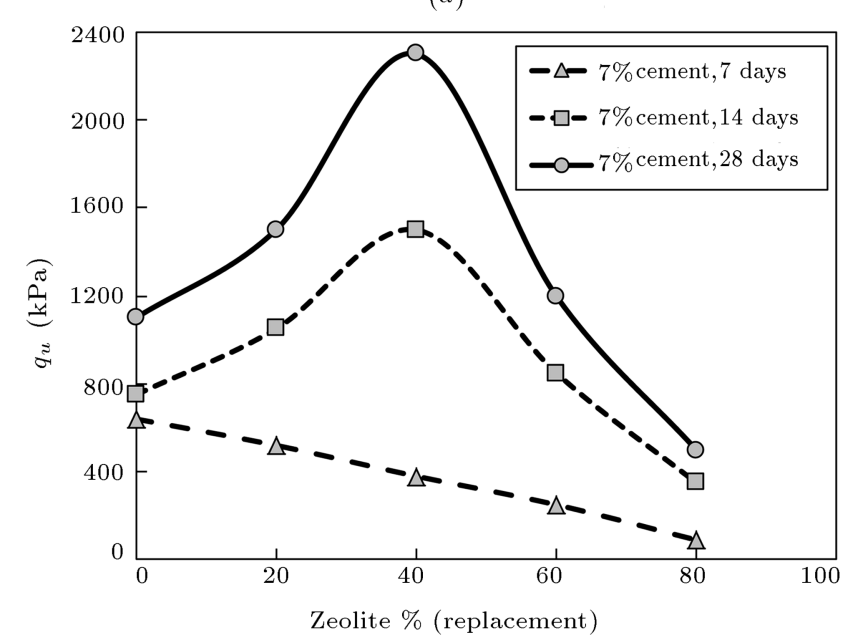

(b)

Figure 6. Effects of zeolite on unconfined compression strength of cemented sand samples.

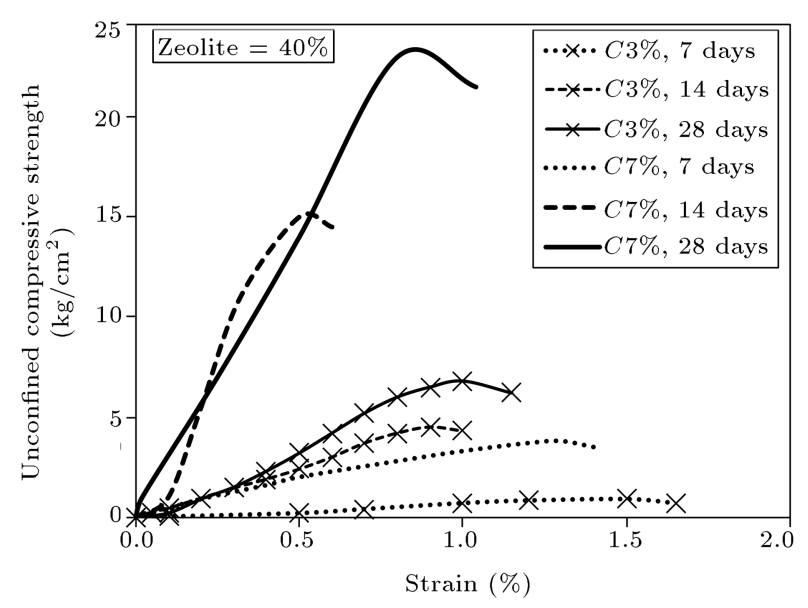

Figure 7. Effect of curing time on stress-strain curves of the zeolite-cemented sand (the optimum cement replacement by zeolite).

of the sample that improves its strength. Figure $8(\mathrm{~b})$ illustrates the downward trend of the samples with 60 and $80 \%$ cement replacements by zeolite, as compared

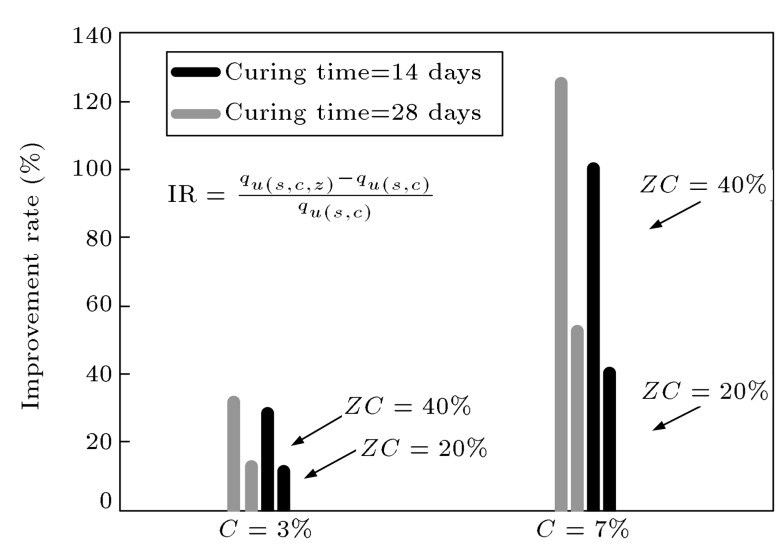

(a)

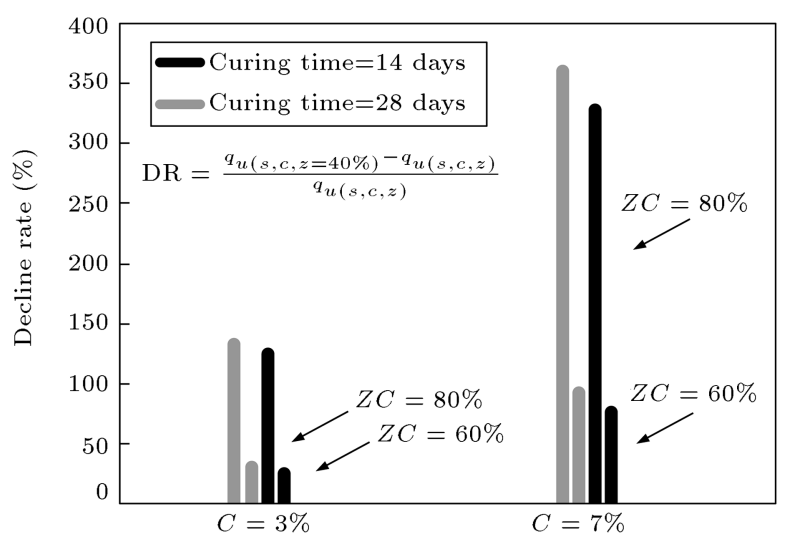

(b)

Figure 8. Variations of (a) improvement rate and (b) a decline rate at the optimum cement replacement of zeolite.

to the sample with an optimal amount of $40 \%$ zeolite $\left(\mathrm{UCS}_{(s, c, z=40 \%)}-\mathrm{UCS}_{(s, c, z)}\right) / \mathrm{UCS}_{(s, c, z)}$. As shown above, adding zeolites more than $40 \%$ results in the compressive strength decline, which is up to $92 \%$ and $360 \%$ for $60 \%$ and $80 \%$ replacements of cement by zeolite (with curing time of 28 days), respectively. This reduction occurs due to the restriction of pozzolanic reaction resulting from higher cement replacement by zeolite. Hence, although adding zeolite as cement replacement has a major effect on the strength improvement of zeolite-cemented sand, it should be limited to $40 \%$ within the circumstances specified in the present study.

\subsection{Small-scale $1 \mathrm{~g}$ model test}

In the second part of this study, a series of smallscale $1 \mathrm{~g}$ model tests were conducted to evaluate the behavior of strip foundation resting on the saturated sand stabilized by a zeolite pad. Based on the compressive strength test's results, the amount of $40 \%$ zeolite was determined as the optimum proportion to precast the zeolite pads. Table 2 shows the properties of the constructed pads with curing time of 28 days for conducting physical model tests.

Figure 9 illustrates stress-settlement curve of the 


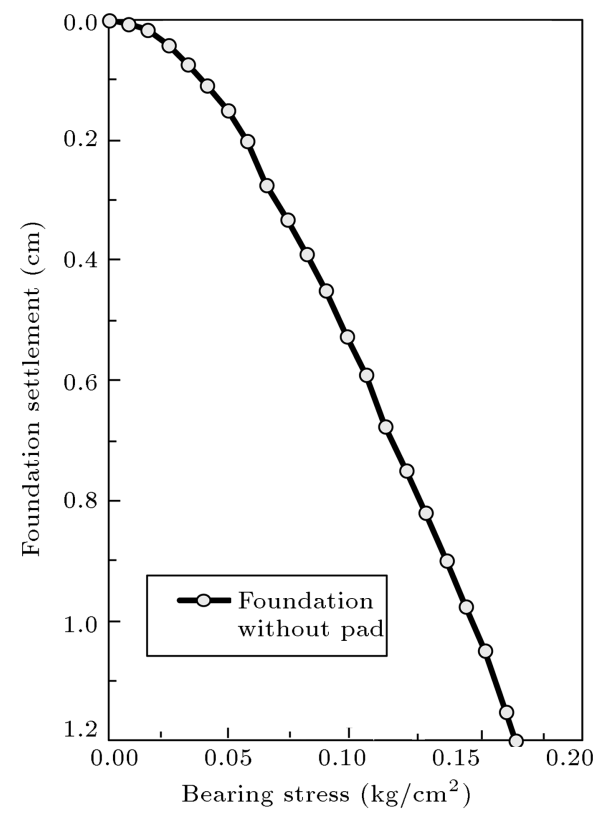

Figure 9. Bearing stress-foundation settlement curve for single strip foundation resting on saturation sand (without pad).

strip foundation resting on the saturated sand without the zeolite pad, which represents the behavior of the sand in loose relative density. Based on the loadsettlement curves obtained by experimental studies, the ultimate bearing capacity of a shallow foundation resting on sandy soil can be determined by several approaches. De Beer [29] suggested that the load corresponding to the intersecting tangents of two linear portions of the load-settlement curve could be defined as the ultimate bearing capacity. However, Vesic [30] and Das [31] described the ultimate bearing capacity as the load corresponding to the settlement of $5 \% \sim 15 \%$ $(S / B=0.05 \sim 0.15)$ and $15 \% \sim 25 \%(S / B=0.15 \sim$

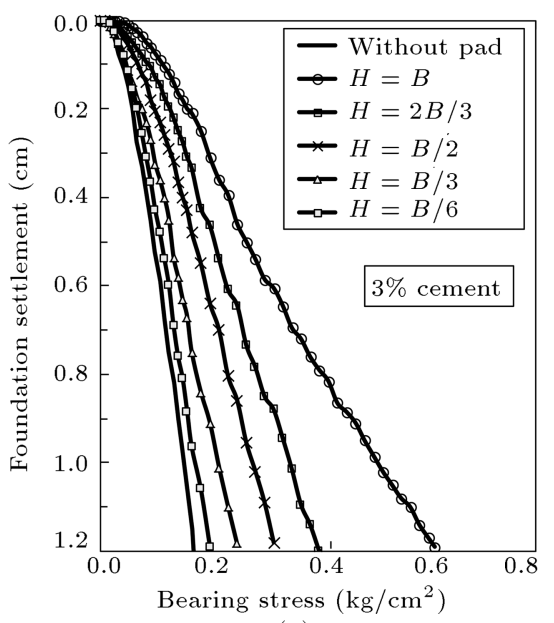

(a)
$0.25)$, where $B$ is equal to the width of foundation. In this study, the ultimate bearing capacity of each footing was determined using Vesic's method [32] with the foundation width of $20 \%$ as the settlement $(S / B=$ $0.2)$.

Since no mechanism was designed and constructed to generate upward seepage in the testing tank and the pore pressure was in the isostatic state, the amount of excess pore water pressure was considered equal to zero for all tests. In addition, the following load application of incremental pore water pressure in piezometers was observable; however, the excess pore pressure dissipated very quickly. Therefore, illustrating the graph of excess pore pressure change was ignored in this study. During load application, the recorded data indicate that excess pore water pressure beneath the foundations is smaller than that beneath the corresponding points in the far-field ground. Therefore, the water under the foundation flows toward the far field. Jafarian et al. [9] came to the same conclusion. Likewise, the same phenomenon due to dilative behavior of the soil underneath the foundation has been observed in centrifuge studies [32-34].

\subsection{Effect of the zeolite-cement pad on the foundation's bearing capacity}

The stress-settlement curves of the strip footing resting on the pads with different thicknesses and two different cement contents of $3 \%$ and $7 \%$ are shown in Figure 10(a) and (b). All the precast pads had an optimum amount of zeolite replacement (40\%) and were cured in 28 days. The ultimate bearing capacity of the foundation without a pad that rested on the saturated sand is equal to $0.15 \mathrm{~kg} / \mathrm{cm}^{2}$. However, the presence of a pad with the thickness of $B / 6$ ( $B$ is width of foundation) underneath the strip foundation

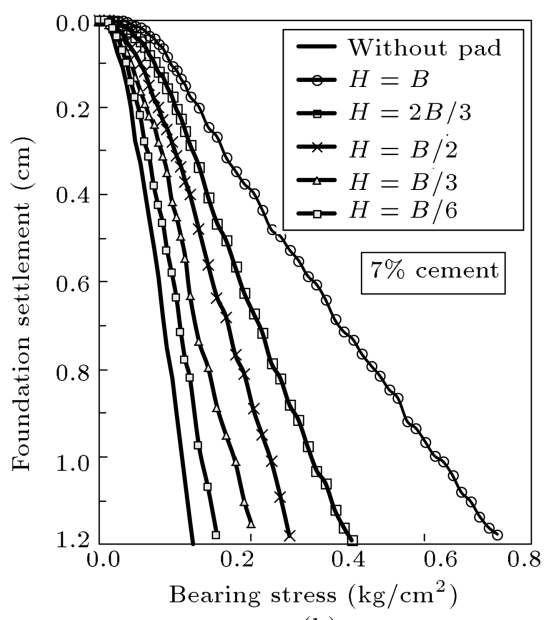

(b)

Figure 10. Bearing stress-foundation settlement curves in the case of different thicknesses of a pad: (a) Cement contents of $3 \%$ and (b) cement content of $7 \%$. (Note that the optimum value of $40 \%$ cement replacement by zeolite and curing time of 28 days were considered for all samples.) 


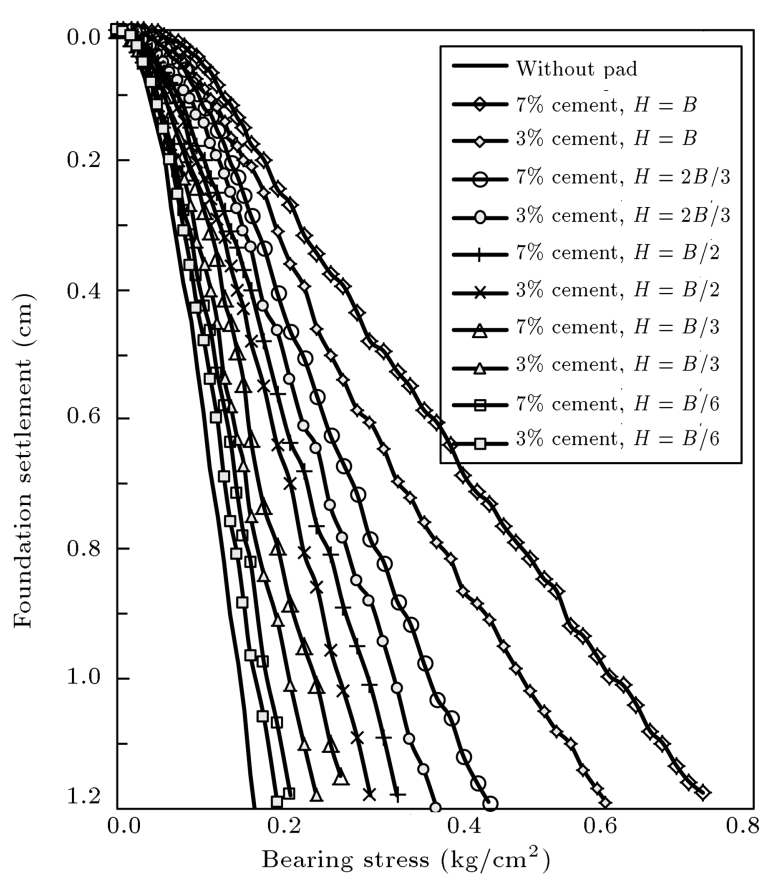

Figure 11. Curves of bearing stress against foundation settlement for all small-scale $1 \mathrm{~g}$ model tests.

increases the ultimate bearing capacity of the cement content of $3 \%$ (Series A1 according to Table 3 ) and the cement content of $7 \%$ (Series A2) up to $0.167 \mathrm{~kg} / \mathrm{cm}^{2}$ and $0.184 \mathrm{~kg} / \mathrm{cm}^{2}$, respectively. However, a comparison between the samples with cement contents of $3 \%$ and $7 \%$ (Series A1 and A2) shows a 9\% increase in the ultimate bearing capacity.

Doubling the thickness of the pad (comparison between Series A and B) increases the bearing capacity of the cement content samples of $3 \%$ and $7 \%$ up to $29 \%$ and $36 \%$, respectively. As shown in Figure 10, an increase in the thickness of the pad increases the bearing capacity and relatively reduces the settlement of foundation. Due to the low thickness and high surcharge pressure in the test Series A, the pad with the thickness of $B / 6$ was crushed during the test. However, in spite of the pad being crushed under the foundation, the bearing capacity increased, as compared with the foundations without a pad.

Figure 11 shows the stress-settlement curves for all conditions presented in Table 3. Accordingly, for the small load ranges, the relationship between the stress and settlement is nonlinear, while it gets a linear trend for the large load ranges. This linear trend might be a result of the punch type of the foundation's failure. Without a doubt, the stresssettlement relationship has to be linear in the very small ranges of the settlement; however, in the precision range used in the current experiments, such linearity is not observed. A comparison between E1 and E2 with the pad thickness equal to the foundation's width and different cement contents shows a $23 \%$ increase in the

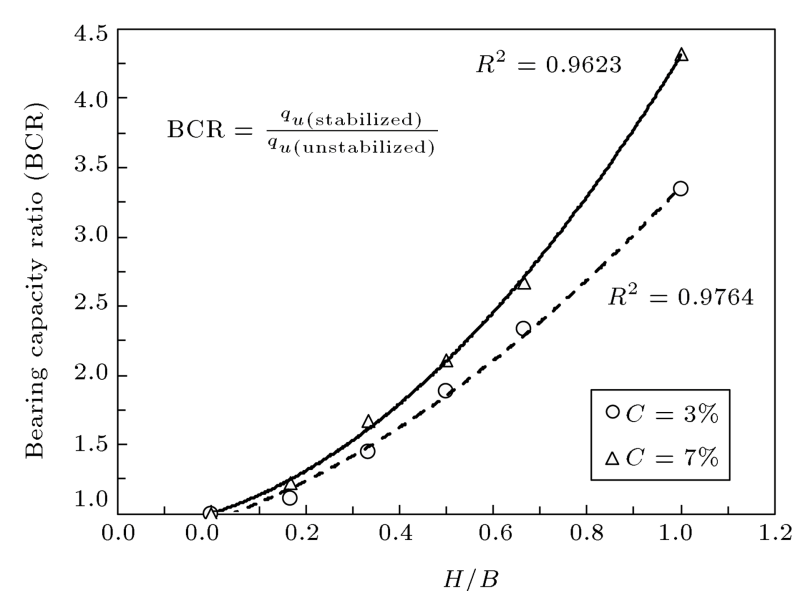

(a)

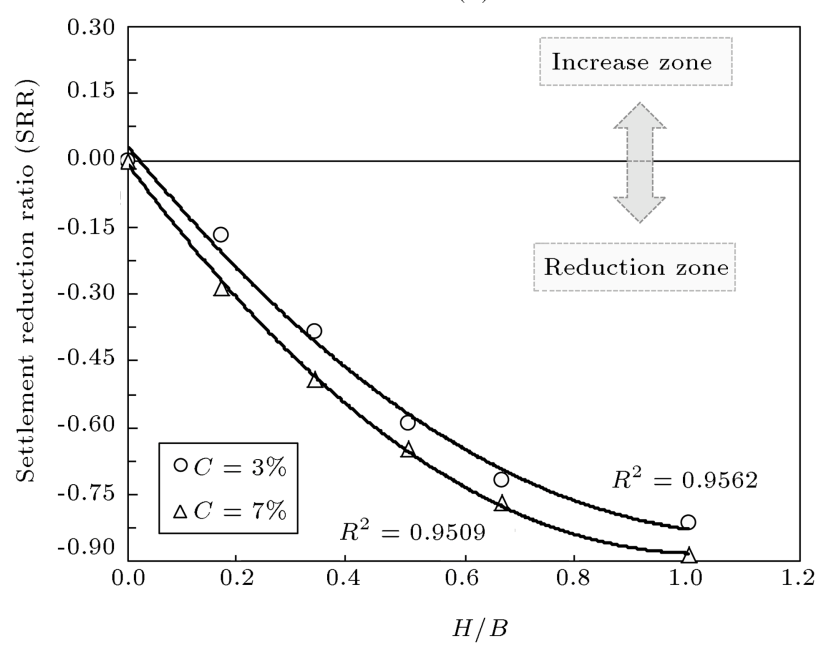

(b)

Figure 12. Variations of (a) BCR and (b) SRR versus $H / B$ ratios for all tests.

bearing capacity. In addition, for Series A, B, C, and $\mathrm{D}$, the rates are $9 \%, 12 \%, 14 \%$, and $19 \%$, respectively. Therefore, the effect of cement content is greater on the thicker pads.

\subsection{Bearing capacity and settlement reduction ratio}

Bearing Capacity Ratio (BCR) is used commonly to compare the test data on stabilized and unstabilized soils, which can be defined by the following equation [35]:

$$
\mathrm{BCR}=\frac{q_{s}}{q_{0}},
$$

where $q_{s}$ and $q_{0}$ are the bearing capacities of the stabilized and unstabilized soils, respectively. The parameter investigated herein includes the pad thickness, $H$, which was normalized by the width of the foundation, $B$.

As shown in Figure 12(a), the values of the bearing capacity ratio evaluated by Eq. (1) were used to evaluate the relationship between $\mathrm{BCR}$ and the 
$H / B$ ratio obtained from Table 3 , where $H / B$ is the ratio of the pad thickness to the foundation width. Accordingly, an increase in $H / B$ ratio results in the $\mathrm{BCR}$ increase. The value of $\mathrm{BCR}$ in the ratio of $H / B=0$ (in the case of a foundation without any pad, $\left.q_{s}=q_{0}\right)$ is equal to 1 ; further to that, the values for $H / B=0.16, H / B=0.33, H / B=0.5$, $H / B=0.66$, and $H / B=1$ are equal to $1.22,1.67,2.12$, 2.67 , and 4.23 , respectively (with the cement content of $7 \%$ ). Moreover, an increase in cement content improves $\mathrm{BCR}$, whereas the impact of the difference between the cement contents of $3 \%$ and $7 \%$ is more pronounced at higher $H / B$ ratios. The coefficients of determination values $\left(R^{2}\right)$ were greater than 0.95 , indicating that the regression lines fit the data properly.

The values of Settlement Reduction Ratio (SRR) for all tests are plotted with the $H / B$ ratio as presented in Figure 12(b). The SRR is defined here as the ratio of the settlement of the pad-stabilized foundation to that of the unstabilized foundation at a specified footing pressure $\left(q=0.15 \mathrm{~kg} / \mathrm{cm}^{2}\right)$.

By placing a pad with the thickness of $B / 6$ (Series A2) beneath the foundation, the settlement rate reduces up to $26 \%$, as compared to the condition in which there is no pad. For the values of $H=B / 3$ (test B2), $H=B / 2$ (Series C2), $H=2 B / 3$ (Series D2), and $H=B$ (Series E2) with the cement content of $7 \%$, the SRR rates decrease up to $65 \%, 76 \%$, and $86 \%$, respectively. Therefore, an increase in the $H / B$ ratio leads to $S R R$ reduction, and the data fall into the reduction zone. In addition, the rates of SRR variation for the cement contents of $3 \%$ and $7 \%$ are the same for all the $H / B$ ratios, containing a range of $6 \%$. Therefore, although the effect of the cement content on the BCR is higher in the higher $H / B$ ratio, it does not influence SRR by increasing the $H / B$ ratio.

\section{Conclusion}

In this study, two series of experiments were performed to investigate the impact of adding zeolite to the cemented sand. In the first series of experiments, 30 unconfined compression strength tests were performed to determine the optimum proportion of zeolite in the cemented sand samples to cement contents of $3 \%$ and $7 \%$ (relative to dry soil mass) and 0, 20, 40, 60, and $80 \%$ replacements of cement by zeolite. In the second series of experiments, the sandy soil was stabilized by the optimum amount of zeolite (40\%) determined from the first series, and some small-scale $1 \mathrm{~g}$ model tests were conducted to evaluate the behavior of the strip foundations resting on the zeolite pad.

The following conclusions can be summarized based on the experimental results of this study:

1. Replacing cement by zeolite up to $40 \%$ (the op- timum zeolite content) causes an increase in the compressive strengths of the samples with curing times of 14 and 28 days up to $40 \%$ to $125 \%$, respectively. This increase in the strength is due to the pozzolanic activity of zeolite and a reduction in hydration reaction in this period;

2. In the case of $40 \%$ cement replacement by zeolite and curing times of 14 and 28 days, specimens with more cement content have a higher increase rate in strength and the higher zeolite effect;

3. Increasing the amount of cement from $3 \%$ to $7 \%$ leads to an increase in the strengths of zeolite and cemented sand from 2.5 to $2.93 \%$ in curing times of 14 and 28 days, respectively. In addition, through the partial replacement of cement by zeolite, the behavior of specimens changes from the brittle state to plastic state at failure;

4. Compared with cemented sand, the compressive strengths for blends with $60 \%$ replacement of cement by zeolite and curing times of 14 and 28 days increase up to $2 \%$ and $9 \%$. Therefore, samples with a $60 \%$ zeolite addition have higher strength than cemented sand samples, whereas increasing the amount of zeolite in samples with curing time of 7 days decreases compressive strength linearly due to the incomplete pozzolanic reaction;

5. Using a pad with the thickness of $B / 6$ increases the bearing capacity of stabilized strip footing for the pads with cement contents of $3 \%$ and $7 \%$ up to $11 \%$ and $23 \%$, respectively, whereas increasing the thickness of pad by 2 times $(B / 3)$ leads to increasing the bearing capacity up to $44 \%$ and $67 \%$. As a result, utilizing pad beneath the strip foundations resting on the saturated loose sand causes an increase in the bearing capacity and a reduction in the settlement;

6. Increasing the $H / B$ ratio results in the increase of the $\mathrm{BCR}$ and a reduction in the SRR. Moreover, increasing the cement content causes an increase of the BCR rate up to $9 \%$ and $23 \%$ for $H=B / 6$ to $H=B$ states, respectively, whereas the SRR rate in this range is constantly $6 \%$.

\section{Nomenclature}

$B \quad$ Width of foundation

BCR Bearing Capacity Ratio

C Cement content

$C_{u} \quad$ Coefficient of uniformity

$D_{r} \quad$ Relative density

$D_{50} \quad$ Mean effective diameter

$G_{s} \quad$ Specific gravity 
$q_{s}$

Bearing capacity of foundation resting on stabilized sand (pad)

$q_{0}$ Bearing capacity of foundation resting on unstabilized sand (without pad)

$q_{u} \quad$ Unconfined compressive strength

$R^{2} \quad$ Coefficient of variation

SRR Settlement Reduction Ratio

$Z \quad$ Replacement of cement by zeolite

$\left(\gamma_{d}\right)_{\max } \quad$ Maximum dry unit weight

$\left(\gamma_{d}\right)_{\min } \quad$ Minimum dry unit weight

\section{References}

1. Mehta, P.K. "Reducing the environmental impact of concrete", Concrete International, 23(10), pp. 61-66 (2001).

2. Damtoft, J.S., Lukasik, J., Herfort, D., Sorrentino, D., and Gartner, E.M. "Sustainable development and climate change initiatives", Cement and Concrete Research, 38(2), pp. 115-127 (2008).

3. Khajeh, A., Mola-Abasi, H., and Naderi Semsani, S. "Parameters controlling tensile strength of zeolite cemented sands", Scientia Iranica A (In Press). DOI: 10.24200/sci.2017.4585.

4. Perraki, T., Kakali, G., and Kontoleon, F. "The effect of natural zeolites on the early hydration of Portland cement", Microporous and Mesoporous Materials, 61(1-3), pp. 205-212 (2003).

5. Caputo, D., Liguori, B., and Colella, C. "Some advances in understanding the pozzolanic activity of zeolites: The effect of zeolite structure", Cement and Concrete Research, 30(5), pp. 455-462 (2008).

6. Canpolat, F., Yilmaz, K., Kose, M.M., Sumer, M., and Yurdusev, M.A. "Use of zeolite, coal bottom ash and fly ash as replacement materials in cement production", Cement and Concrete Research, 34(5), pp. 731-735 (2004).

7. Tuncan, A., Tuncan, M., Koyuncu, H., and Guney, Y. "Use of natural zeolites as a landfill liner", Waste Management \& Research, 21(1), pp. 54-61 (2003).

8. Jafarian, Y., Mehrzad, B., Lee, C.J., and Haddad, A.H. "Centrifuge modeling of seismic foundation-soilfoundation interaction on liquefiable sand", Soil Dynamics and Earthquake Engineering, 97, pp. 184-204 (2017).

9. Jafarian, Y., Haddad, A., and Mehrzad, B. "Loadsettlement mechanism of shallow foundations rested on saturated sand with upward seepage", International Journal of Geomechanics, 17(3), pp. 1-14 (2016).

10. Dash, S.K., Krishnaswamy, N.R., and Rajagopal, K. "Bearing capacity of strip footings supported on geocell-reinforced sand", Geotextiles and Geomembranes, 19(4), pp. 235-256 (2001).

11. ASTM D422 "Standard test method for particle-size analysis of soils", ASTM International, West Conshohocken, PA (2003).
12. Jafarian, Y., Ghorbani, A., Salamatpoor S. and Salamatpoor, S. "Monotonic triaxial experiments to evaluate steady-state and liquefaction susceptibility of Babolsar sand", Journal of Zhejiang University Science-A, 14(10), pp. 739-750 (2013).

13. Jafarian, Y., Javdanian, H., and Haddad, A. "Dynamic properties of calcareous and siliceous sands under isotropic and anisotropic stress conditions", Soils and Foundations, 58(1), pp. 172-184 (2018).

14. Salamatpoor, S. and Salamatpoor, S. "Evaluation of Babolsar sand behaviour by using static triaxial tests and comparison with case history", Open Journal of Civil Engineering, 4(3), pp. 181-197 (2014).

15. ASTM C150/C150M-17 "Standard specification for Portland cement", ASTM International, West Conshohocken, PA (2017).

16. ASTM C114-11 "Standard test methods for chemical analysis of hydraulic cement", ASTM International, West Conshohocken, PA (2011).

17. ASTM D2166 "Standard test method for unconfined compressive strength of cohesive soil", ASTM International, West Conshohocken, PA (2006).

18. Ladd, R.S. "Preparing test specimens using under compaction", Geotechnical Testing Journal, 1(1), pp. 16-23 (1978).

19. Liu, C. and Evett, J.B., Soils and Foundations, 4th Edn., Pearson Education, New Jersey (2004).

20. ASTM D1194-72 "Standard test method for bearing capacity of soil for static load and spread footings", ASTM International, West Conshohocken, PA (1987).

21. Wood, D.M., Geotechnical Modeling, E. \& F.N. Spon Press, London (2004).

22. Vargas-Monge, W. "Ring shear tests on large deformation of sand", Ph.D. thesis, University of Tokyo (1998).

23. Bishop, A.W., Green, G.E., Garga, V.K., Andresen, A. and Brown, J.D. "A new ring shear apparatus and its application to the measurement of residual strength", Géotechnique, 21(4), pp. 273-328 (1971).

24. Kagawa, T. "On the similitude in model vibration tests of earth structures", In Proceedings on Japan Society of Civil Engineers, pp. 69-77 (1978).

25. Iai, S. "Similitude for shaking table tests on soilstructure-fluid model in $1 \mathrm{~g}$ gravitational field", Soils and Foundations, 29(1), pp. 105-118 (1989).

26. Towhata, I., Earthquake Geotechnical Engineering, Springer, Berlin (2007).

27. Otsubo, M., Towhata, I., Hayashida, T., Liu, B. and Goto, S. "Shaking table tests on liquefaction mitigation of embedded lifelines by backfill with recycled materials", Soils and Foundations, 56(3), pp. 365-378 (2016). 
28. Mitchell J.K. "Soil improvement-State-of-the-art report", In Proceedings of the 10th International Conference on Soil Mechanics and Foundation Engineering, Balkema, Rotterdam, Netherlands, pp. 509-565 (1981).

29. De Beer, E.E. "Experimental determination of the shape factors and the bearing capacity factors of sand", Géotechnique, 20(4), pp. 387-411 (1970).

30. Vesic, A.S. "Analysis of ultimate loads of shallow foundations", Journal of the Soil Mechanics and Foundations Division, 99(1), pp. 45-73 (1973).

31. Das, B.M., Shallow Foundations: Bearing Capacity and Settlement, 2nd Edn., CRC Press (2009).

32. Liu, L. and Dobry, R. "Seismic response of shallow foundation on liquefiable sand", Journal of Geotechnical and Geoenvironmental Engineering, 123(6), pp. 557-567 (1997).

33. Adalier, K., Elgamal, A., Meneses, J. and Baez, J.I. "Stone columns as liquefaction counter measure in non-plastic silty soils", Soil Dynamics and Earthquake Engineering, 23(7), pp. 571-584 (2003).

34. Dashti, S., Bray, J.D., Pestana, J.M., Riemer, M. and Wilson, D. "Mechanisms of seismically induced settlement of buildings with shallow foundations on liquefiable soil", Journal of Geotechnical and Geoenvironmental Engineering, 136(1), pp. 151-164 (2010).

35. Binquet, J. and Lee, K.L. "Bearing capacity tests on reinforced earth slabs", Journal of the Geotechnical Engineering Division, 101(12), pp. 1241-1255 (1975).

\section{Biographies}

Sina Salamatpoor is currently a $\mathrm{PhD}$ candidate in Geotechnical Engineering at Islamic Azad University of Najafabad, Iran. He also received his BSc (2010) and MSc (2012) degrees in Civil Engineering from Islamic Azad University (Ayatollah Amoli Branch) and Geotechnical Engineering from University of Guilan, Iran, respectively. He has been working from 2010 to the present time on projects as a structural and geotechnical consulting engineer in various construction companies. Subsequently, he was awarded the first rank in 2012 among the Civil Engineers in Mazandaran Construction Engineering Organization, Iran.
His research interests include testing and modeling of geotechnical materials, finite-element modeling, and its applications to geotechnical engineering, numerical and experimental investigations of soil improvement, advance soil mechanic, soil liquefaction, geotechnical earthquake engineering, foundation engineering and geo-engineering education. To date, he has published various scientific papers in journals and conferences as an author or co-author.

Yaser Jafarian is currently the faculty member of International Institute of Earthquake Engineering and Seismology (IIEES). He started the academic activity as an Assistant Professor at the Civil Engineering Department of Semnan University since 2009 and, then, moved to IIEES. His professional research fields involve multiple areas of geotechnical earthquake engineering including dynamic soil properties, soil liquefaction, seismic stability and displacement of earth slopes, probabilistic geohazard analysis, and dynamics analysis of seafront structures. Currently, he has focused on physical and numerical modeling of foundations and quay walls tolerating large seismic ground deformations such as liquefaction condition. He has also been involved in analysis and design of various routine and complicated projects including geotechnical site investigation, soil improvement (micropile, stone column, nailing, etc.), analysis and design of marine geotechnical structures (breakwater, quay walls, etc.). Dr. Jafarian published his researches' outcomes in more than 25 journal papers, 40 conference proceedings, and 4 technical reports.

Alborz Hajiannia is an Assistant Professor at the Department of Civil Engineering in Islamic Azad University of Najafabad, Iran. He received his MSc (2000) and PhD (2012) degrees in Geotechnical Engineering from Amirkabir University of Technology. His research interests are numerical and experimental investigations of soil improvement, advance soil mechanic, geotechnical earthquake engineering, slope stability, and foundation engineering. 